\title{
DEVELOPMENT CENTERS AND CENTRAL PLACES IN WEST GERMAN REGIONAL PLANNING SCHEMES
}

\author{
Gunter Krumme*
}

University of Washington

\section{INTRODUCTION}

In spite of an increasing American interest in European regional development patterns and planning approaches, English-language reports on the West German scene have remained scarce compared with those of other continental countries such as France and Italy (Cf., however, Storbeck 1965; Boventer 1969; Commission 1969; Mayhew 1969; OECD 1970). While France has become a classic example for capital-city agglomeration problems and centralized regional planning approaches, and Italy for North-South inequalities and largescale regional investment projects, Germany attracted attention mainly for her national growth patterns and national economic policies. The following reasons shall be offered for this neglect:

1. the delayed awareness of regional problems in Germany;

2. the variety of regional and spatial planning approaches resulting from the federal structure of the West German governmental system and the prevailing uncertainty about the constitutional allocation of regional planning authority among governmental levels. (The major responsibility for "Raumordnung" and "Landesplanung" lies with the ten "Lander"leaving to the federal government in ill-defined authority for establishing guidelines in addition to regional economic policies.)

3. the lack of really grave regional development problems as they exist in some other European countries.

Three factors seem to have assisted in creating this relatively favorable overall picture of regional development: (Commission 1969, p. 88).

1. the relatively favorable pattern of distribution of towns and industrial centers;

2. the general climate of economic growth,

3. the manpower shortage which appeared after attainment of full employment.

Nevertheless, Germany has its share of regional problems worthwhile to be analyzed. In fact, due to its relatively favorable economic growth experience and balanced spatial patterns, the regional problem has the characteristic of being without any specific focus. What problem regions do have in common is that they are either located close to the Iron Curtain and thus have as sumed a historically unfamiliar peripheral position, or that their socioeconomic, specifically rural-agricultural conditions, possibly in combination with their physical endowments and a lack of political foresight, have delayed structural adjustments.

Thus, apartfrom a few emergency-type regional unemployment schemes (e.g., the Emsland Plan), regional policies and spatial planning approaches

*The author gratefully acknowledges financial assistance by Grant No. GS-27731 of the National Science Foundation. 
are operating on a level where simplistic regional shot-gun methods which have no other objective but to alleviate speedily large-scale unemployment have no place. What was recognized as being necessary and what has been attempted in recent years we re coordinated regional policies and spatial planning schemes which are differentiated enough to be tuned to the specifics of a regional imbalance without losing sight of interregional effects and other regions' interests. Planning approaches increasingly shifted from attacking symptoms to correcting the origins of regional inequities, i.e., to prophylactic regional planning approaches. More specifically, regional economic policies are now being vertically and horizontally coordinated and--together with other non-regional, but regionally significant economic policies--molded into "regional action programs." At the same time, the spatial organization of society as a whole is being reconsidered and incrementally manipulated by spatial planning schemes (Raumordnung) such as the nation-wide central place program. Thus, although Germany is nowhere near reaching the per capita GNP of the United States or even certain other European countries, its lack of widespread, large-scale inequalities in combination with its increasingly sophisticated awareness of regional imbalances which still exist and continue to be generated by a booming economy, makes an analysis of German regional planning and spatial organization schemes particularly interesting in view of the avalanching theoretical literature in this field.

\section{PROCESSES OF CONCENTRATION AND DISPERSION}

Whereas the pattern of industrial change of the period until 1953 was dominated by the redistribution of refugee industries, reconstruction of war damages, and the boom of new, small manufacturing enterprises, the subsequent years show a rapid decline in the importance of the postwar adjustment within the general pattern of industrial growth and structural change. The analysis of the spatial components of the growth patterns of manufacturing activities reveals certain trends in the sizes of new establishments and places of location. These trends developed in strong association with the changes in the rates of unemployment.

The period from 1953 until 1959, the year when full employment had been attained by most sectors and regions in Germany, ${ }^{1}$ clearlywas dominated by a process of agglomeration in and a round the estahlished industrial districts (Weigt, 1959). Labor not being scarce to any significant extent at that time, other factors such as the advantages of being located close to input-output markets prevailed and forced rural un- or underemployed workers to migrate to the cities or to commute over often substantial distances. The prior dispersive effect of the dependence on agricultural production and proximity to food supplywas replaced by the agglomerative influence of the revitalized urban infrastructure, production facilities, and channels of communication. Indeed, the agglomerative tendencies of the 1950's were reinforced by the competition of larger cities to regain their prewar population size.

However, most authors agree that, compared with the 1930 's or even the twenties, the Federal Republic is not any more "agglomerated. "Borries (1969, pp. $25 \mathrm{ff}$.) identifies fifty urban agglomerations where $50.1 \%$ of the population lived in 1961 on $13 \%$ of the total area. The corresponding figures for 1939 and 1925 were 51.5 and 51.0 respectively. On the whole, it seems that the speedy restoration of prewar spatial patterns was considered to be the only guarantee for economic recovery. The realization that such a policy eventually (under the conditions prevalent in Germany at that time) would lead to regional imbalances which are inconsistent withother aspects of a "social-market-economy" policy, resulted in effective regional measures only after the agglomerative forces had already been considerably decreased by the changes on the labor market. 
The change from unemployment to full employment in the late 1950's resulted in significant dispersivetendencies during the subsequent years. The ensuing labor shortage in the industrial agglomeration areas led in many industries literally to Hotelling-type branch plant location games with plants and "extended work-benches" trying to locate even closer to the source of the agricultural labor force underutilized or set free by mechanization. ${ }^{2}$ Clearly, this type of single-reas on decentralization and regional industrialization was heavily dependent upon development in the advanced regions and generated little induced growth. Thus it could hardly be considered a contribution to a regional economic structure one which provides cyclical stability and occupational diversity, since most of these labor-intensive activities tended to be specialized with respect to industrial branch, functions performed, and their positions within corporate structures.

It should be pointed out that during the last few years of the over-employment period (before the recession in 1966), the size of communities selected by newly established plants had become remarkably small (see Table 1 for period 1964-65). The most important reason for locating in these communities was "availability of labor force" or, better, "unavailability of labor anywhere else" (Jochimsen and Treuner, p.44). It has been found that relatively more branch plants were located in small communities (with less than 3, 000 population; loc. cit., p. 41), and, that newly established and relocating firms were more frequent in larger communities, particularly those with a size between 3,000-10,000. It seems that the willingness of industries to shift into rural, village and small-town locations during this period of dramatic labor shortage has largely influenced subsequent spatial industrialization policies (whichassumed that this short-runwillingness of farm labor to switch to industrial jobs without changing location also represents their longrun desires). ${ }^{3}$

\section{REGIONAL ANDSPATIAL POLICY AND PLANNING SCHEMES IN POSTWAR GERMANY}

Germany's spatially significant planning and Federal policy efforts can be roughly divided into three groups:

1. spatial planning policies, that is, government efforts designed to influence (quantitatively and qualitatively) the spatial structure of settlement patterns and population distribution known as "Raumordnung" in general, and the "central place program" in particular;

2. regionaleconomic policies, that is, the deliberate and explicit economic measures aimed at industrialization processes in designated Federal Promotion Areas ("Bundesforderungsgebiete"); and

3. other economic and social policy measures which have more or less regional or spatial significance, for example, agricultural subsidization programs and transport investment policies; these will not be specifically considered in this paper.

In many ways, and in spite of their differing objectives, regional and spatial policies have been complementary. While one of the maingoals of regional economic policies was the mobilization of regional growth potentials for national growth objectives and, thus, become a major part of Federal economic policies only after bottlenecks occured in traditional growth regions, the major aim of spatial planning was to improve living conditions in rural and depressed areas by correcting socially insufficient spatial settlement patterns.

Due to the relatively narrow definition of regional economic policy, the 
third group of measures (agriculture, transportation, military and government expenditures, environmental protection policies, etc.) is highly significant for regional development planning. This realization has recently led to increasing coordination and integ ration of such policies into regional and spatial planning considerations (cf. BROB, 1970).

\section{SPATIAL PLANNING AND CENTRAL PLACES}

\section{Raumordnung: Leibilder and Objectives}

The concept of "Raumordung" is--in contrast to specific regional planning concepts--goals-oriented. The term "Raumordnung" has the double, interrelated meaning of "spatial arrangement "or "spatial organization" as well as "spatial orderlines" with its obvious differences in implied value judgement. The literature which tries to conceptualize around the necessity for spatial planning is clearly split along these lines. In general, university regional scientists tend to interpret "Raumordnung" as a mandate of the federal constitution to be concerned about spatial structure of society without accepting any a priori commitment for a specific spatial arrangement. On the other hand, government institutions and government sponsored research institutions tend to interpret "Raumordnung" as a normative concept--an orderly image of social, cultural and economic space. The definition of "Raumordnung" found in the "Handwörterbuch für Raumordnung" clearly reflects this latter interpretation: "Raumordnung is the image of an order which is appropriate for the social, economic and cultural requirements. In this sense, Raumordnung is the task, posed to the government as part of its general welfare-oriented functions, to strive continuously for a spatial order which represents the present image (Leitbild) of society" (Hansmeyer, 1968, p. 42).

Clearly, therewas a lack of workable planning concepts when the Spatial Planning Law of 1965 (BROG) was conceived and formulated. 4 The result was that a relatively large number of fuzzy terms were invented for its formulation which had no operational or even conceptual meaning. This, in turn, led to the unfortunate situation that these "empty terms" had to be substantiated ex post with conceptual and operational content. Thus, following the enactment of the Spatial Planning Law, the government commissioned research projects with the dual functian to justify (ex post) the use of certain terminogy by creating new or manipulating existing concepts, and, at the same time, to suggest criteria to identify the corresponding regional phenomena in reality. The most dramatic case of vague terminology was the use of the term "healthy" for identifying "healthy structures and living conditions" (cf. Isbary et al., 1969). The corresponding section in the BROG 1965 (\#2, Abschnitt 6) reads like a physician's handbook.

In agglomerated areas with healthy spatial living and working conditions as well as a balanced economic and socialstructure these conditions and structures shall be secured and, if necessary, improved. Agglomeration of residential and employment centers which is leading to unhealthy spatial living and working conditions as well as to unbalanced economic and social structures shall be counteracted. Wherever such unhealthy conditions and unbalanced structures exist their convalescence shall be supported.

Compared to the extensive German literature dealing with spatial images, references to more method-oriented, operational objectives are very few indeed. The realization that the final formulation of the Bundes raumord-nungsgesetz of 1965 was unable to ascend from the general ideological non-operational level to a more scientific formulation, led some authors to advocatea shift in the discussion away from ideal goals to that of realistic possibilities 
of evaluating impacts of specific regional policy instruments (Böventer, 1967. pp. 284ff. and Zimmermann, 1966, pp. 244ff). Fuzzy goals which hardly ever can be precisely formulated will always need to be substantiated by concrete methods; why not, these authors ask, start with available methods and critically weigh their expected outcomes in terms of marginal improvements?

Fortunately, the necessity to operationalize the vague Raumordnungs "images" has forced government researchinstitutions to relinquish much of its ideologicaly colored, value-laden terminology in favor of unpretentious, clear, though sometimes very simplistic scientific concepts. The mandate of equalizing living conditions in all parts of the country has been interpreted to mean the achievement of an equal distribution and quality of social inf rastructure facilities. Only for the "Zonenrandgebiet" has it been stated that its ecnomic potential has to be strengthened with the objective that in all of its parts, its living and working conditions as well as its economic and social structure should equal those of the Federal Republic.

\section{Central Places}

The Federal "Spatial Planning Act" (BROG 1965) singled out central places as a special spatial category and planning tool useful for characterizing and manipulating spatial arrangements. The states were asked to specify for their respective areas of jurisdiction central places in acceptable distances to all inhabitants, and to assist in the development of adequate infrastructure services for such central places. The Spatial Planning Act indicated the necessity of consultations and coordination of spatial planning problems between the Federal and state governments before the provisions of the Act were substantiated. An administrative agreement, in 1967, between these two levels specified the details of this vertical and horizontal cooperation and also established the State and Federal Inter-governmental Cabinet Commission for Spatial Planning (MKRO--Ministerkonferenz fur Raumordnung) as well as several sub-committees (BROB, 1968, p. 85). On the level of the Federal government, coordination takes place within an Intra-Cabinet Committee for Spatial Planning (IMARO--Interministerieller Ausschub für Raumordnung).

In 1968, the MKRO identified criteria as well as a framework for the determination of central places by the states. Four levels of central places were prescribed:

1. Oberzentrum

2. Mittelzentrum

3. Unterzentrum

4. Kleinzentrum

Simultaneously, various infrastructure services with different central place characteristics (primarily educational, health, sport, and cultural facilities) were allocated to specific central place levels (Kroner, 1970, pp. 99-100).

With respect to the spacing of central places (that is, the influence of distances on the determination of central places), the following guidelines were established (BROB, 1968, p. 149):

The acceptable distance to a central place depends on the centrality level of that central place and the frequency of necessary visits. It has to be acceptable in terms of time and costs involved. Central places for the supply of basic services (Bahbereichsversorgung) ought to be reached by public transportation within half an hour, a medium center should be within reach of one hour. 
Subsequent legislation by the states has in some cases identified desirable physical distances. Thus, the Raumordnungsplan for Schleswig-Holstein (1969) recommends that neighboring central places should be at least six kilometers apart (to avoid getting in each other's way) and that the re should be a central place within ten kilometers of each residence (Kroner, 1970, p.100).

The problem as it was posedwas: "How many settlement units (corearea with hinterland) on all levels of centrality a re necessary, with due consideration of social and economic constraints, to serve--by concentrating local and regional supply facilities and utilities--the entire population of the Federal territory in such a way as to permit every citizen to develop his individual personality within the community?!" (Isbary, 1965, p. 31).

\section{Central Places and States}

The way in which the individual states have interpreted and implemented the Federal mandate differswidely. Some states have so farmerely acknowledged their central place determination responsibility. The Spatial Planning Program (Raumordnungs-programs) of the state of Hessen in 1967 just points out that "Central places have to be determined in which a diverse supply of economic, social, and cultural services shall be developed" (Kroner, 1970, p. 103). The Spatial Planning Program of the Saa rland does not go much further: (Kroner, 1970, p. 107).

In all parts of the state central places are to be determined or to be projected and supported . . . The classification of the communities of the Saar into centrality levels and the determination of their aspiredfacilities will be the object of a spatial-planning-sub plan. They will be based on existing centralities and the expected development of the different parts of the state.

Some states (such as Bavaria and Nordrhein-Westfalen) have progressed to inventory-type surveys of central places and their present hinterland, while still others (such as Schleswig-Holstein and Niedersachsen) have actually determined a system of planned central places into which the present, unsatisfactory, system is to be converted. These state plans distinguish between those central places which have reached their desired hierarchical level already and those where certain functions need to be added or improved in order to meet the qualifications for its planned central place role (Kroner, 1970, p. 101).

General differences exist in terms of terminology for identifying centers of varying levels, size requirements for the respective hinterlands, the degree to which the suggested four-level scheme has been further disaggregated, and whether or not the states delegate the determination of the lower-order centers to Government Districts (Regierungsbezirke) or postpone it until the formulation of specific regional "Raumordnungspläne." Thus, for example, in the Southwest (Baden-Wurttemberg and Rheinland-Pfalz) the centers of a given level have on the average a smaller size than in Northern Germany.

It seems that the state of Schleswig-Holstein has so far come closest to overcoming the shortcomings of a rigid a priori central-place scheme by allowing for a degree of vertical shifting of functions within the hierarchical set-up, thus being better able to tune the planned range of functions to the specific situation (size, spacing, hinterland, existing specializations etc.) of a central place. Some states, specifically Nordrhein-Westfalen and Baden Würtiemberg, have gone a step beyond the acceptance of a hierarchical system for their planning of functional organization. Employing the idea of a "development axis," development is projected to take place along bands or 
zones linking major central places and passing through medium and lower centers. It seems, however, at this point, that the introduction of development axes is more an adjustment to a present development situation rather than the implementation of a well-understood concept. On the other hand, there seem to be theoretical grounds for assuming that--after having accepted the idea of a decentralized coordinated system of growth centers or central places (instead of individual, relatively large and independent growth centers) - - the efficiency of such systems may be increased (particularly in terms of generating juxtaposition economies) by developments outside of the centers along high accessibility corridors.

\section{REGIONAL ECONOMIC POLICY AND DEVELOPMENT CENTERS}

\section{Principles and Objectives}

Regional economic policyobjectives are much more restricted in scope than those of the Raumordnungs-Syndrome. They are pragmatic, tangible, and definable on the basis of a few economic indicators calculated on a county basis such as Gross Domestic Product, unemployment - and seasonal unemployment rates, percent of population employed in industrial activities "Industriebesatz", and commuter and out-migration rates. There is still no specific legislative act and no precise formulation of overall objectives. However, in its "Strukturbericht 1969," the Bundeswirtschaftsministerium describes some of its tasks in the field of regional policies which, together with sectorial policies, comprise the "Strukturpolitik" (BWM, 1969b, pp. 4f).

The objectives of 'Strukturpolitik' for the sphere of regional economic structure result from:

a) the necessity to create an optimal economic structure in order to ensure that unused and underutilized factors of production are being mobilized for economic growth and from the mandate of the constitution (Grundgesetz, Article 72 ) to guarantee equal living conditions;

b) the task to facilitate adjustment processes which result from structural problems in already developed regions; and

c) the problems of Germany's division and the related separation of a grown domestic economic unit (Economic assistance for Berlin and the "Zonenrandgebiet").

These general objectives led to specific regionalpolicy measures. The authorization and limitation for various assistance programs are based on certain principles which have been accepted also by the states (Länder). These principles emphasize:

a) assistance of investments in growth industries ("Längerfristig aussichtsreichen Bereiche dergewerblichen Wirtschaft") in harmony with the "principles of regional economic policy"';

b) assistance in the expansion of infrastructure facilities, particularly, with the objective of improving the prerequisites for creating new industrial jobs; and

c) development of tourism in appropriate regions. 
2. The Federal Promotion Programs

The Federal Regional Economic Policy can be divided into the following categories:

1. the promotion of depressed regions (since 1951) which were, successively, called Notstands gebiete (emergency a reas), Sanierungsgebiete (recovery a reas), and Bundesausbaugebiete (Federal expansion areas, since 1965). The main features of this "areal support program" were low interest loans or investment subsidies for the new establishment, conversion, rationalization, modernization, and expansion of production plants as wellas loans for tourist facilities. In three states, more than $50 \%$ of the total a rea belongs to this regional assistance program: Schleswig-Holstein $(90 \%)$, Niedersachsen $(61 \%)$, and Bavaria (51\%). (Wiek, 1967, p. 57).

2. the promotion of the Zonenrandgebiet (since 1953)--a 40 kilometer wide strip of land along the Iron Curtain--which is subject to various kinds of Federal support aimed at reducing the implications of structural change resulting from the changed economic orientation of this region. Only a part of the Zonenrandgebiet also belongs to the Federal Expansion Areas (Bundesausbaugebiete). Large parts are well industrialized and do not qualify for regular regional assistance (Wiek, 1967, p. 58).

3. the promotion of growth centers, a project initiated in 1959; the number of growth centers increased from sixteen in 1959 to eighty-one in 1970. Initially referred to as "Development prog ram for central places in rural, structurally weak areas," in 1965 the name was changed to "Bundesausbauorte" or Federal Development Centers. The size of these centers varies significantly between a population of about 5,000 and 35,000 with the majority of them having a size a round 10,000. There seems to have been a slight increase in the size of the more recently determined centers. As suggested by the states, the finaldetermination is made--similarly to the Ausbaugebiete (promotion areas)--by an inter-departmental commission of the Federal government ("IMNOS"; Albert, 1970, pp. 237).

Industrial assistance is provided in the form of:

a) means for developing industrial land,

b) introduction and expansion of industrial infrastructure facilities, and

c) loans to newly locating firms (Kroner, 1964, p. 451).

Until 1963, direct subsidies to industrial firms were based on the number of jobs created; thereafter, the basis became the amount of total capital invested.

4. the "Regional Aktion Programs" (since 1969). This new project had been proposed by the Federal Ministry for Economic Affairs for the intensification and coordination of the regional and structural policy of the Federal government in lagging regions. Initia$11 y$, twelve regional action programs were accepted by IMNOS on the basis of development plans prepared by the states. The total area of these action regions $(119,000 \mathrm{sq}$. $\mathrm{km}$.) comprised almost half of the Federal territory with about $\frac{1}{4}$ of the total population. 
Meanwhile, this program has been expanded to twenty regions.

The main feature of this program is a coordinated, regionalized, and spatially concentrated attack on the former Bundesausbaugebiete or Federal development areas. Objects of this concentration or so-called "gewerbliche Schwerpunkte, "294 of which has been selected by 1970. The average population of a Schwerpunkt and its commuting hinterland was at that time 62, 400 for the country as a whole; the Holstein Action Region in the North leading with an average of 187, 500 and Ostbayern (Eastern Bavaria) tailing with 29,400 (here the minimum of 20,000 was not always fulfilled). (Albert, 1970, p. 249).

In the regional action programs, subsidies and actions are being jointly planned and financed by Federal and state governments and projected for a period of five years. This cooperation between Federal and state governments has been codified by the "Gesetz uber die Gemeinschaftsaufgabe 'Verbesserung der regionalen Wirtschaftsstruktur" of October 6, 1969. Thus, since 1970, regional policy, that is, the "improvement of regional economic structures has been a "Joint Task."

The overriding objective is the creation of new industrial jobs in growth centers within designated action regions. These planning objectives have been quantified and are, for example, for the action region Holstein, 20, 750 new jobs (or 14 new jobs per 1,000 population), and, for the Lower-Saxon Zonenrandgebiet, 35,000 (or 12 per 1,000) for the first five-year planning period (Raum und Ordnung, No. $11 / 12,1969$, p. 4).

Additional benefits of this coordinated regional assistance program a re that:

(a) the diverse regional assistance programs, their complementarity and competitiveness are becoming moretransparent;

(b) the action programs, at the same time, supply the basis for identifying possible additional financial needs for a region as well as allowing expostanalyses of the developmental responsiveness of the region to prior subsidies; and

(c) the participation of various regional planning agencies and the revolving nature of the five-year projections and planning schemes are supposed to stimulate regional initiatives and competition between the "action regions." (Albert, 1970, p. 248).

The subsidies given to these growth centers within the regional action program regions consist primarily of grants and loans with favorable interest rates. The total subsidization value cannot exceed either 10, 15, 20, or $25 \%$ of investment outlays. This subsidization value represents the presentage which expresses the sum of all grants, interest grants as well as interest advantages in the case of loans. The subsidy rate of any particluar growth center depends on whether or not it is located within the Zonenrandgebiet (where it is higher) and whether it is declared a higher-level growth center (übergeordneter Schwerpunkt). (Brink and Kroner, 1970, p. 59). Thesegrants 
are given for establishing new plants, or, to existing plants if they expand their employment by at least $20 \%$.

\section{CONCEPTUAL DISCUSSION AND CRITIQUE}

Central Places and Development Centers: Terminology and Concepts

At this point, the reader must have come close to sharing the confusion with which every outside investigator of German's scientific and political use of the concept and term "central place" inevitably is confronted. In an attempt to clarify this confusion, the following uses of the termcentral place could be distinguished.

1. There is the (more or less) purely deductive, normative central place model associated foremost with the names of Cristaller, Lösch, and Beckmann. It is noteworthy that, in Germany, apart from the work of Böventer and Beckmann, little has been done since Lösch, hardly any by the more inductively inclined German geographers.

2. Much moreappealing for the Germanscientific community, at least in the field of geography, has been the empirical manifestation of the central place phenomenon. The methodological discussion centered largely around the benefits and shortcomings of various ways of identifying the centrality of places. The empiric work encroached upon and completed a painstakingly thorough inventory of central places in post-war Germany. The Institute fur Landeskurde (Bad Godesberg) played the leading coordinating role in this research. ${ }^{5}$ Main parts of the empiricinvestigation were commissioned to University Geography Departments and have led to countless meticulous, but theoretically less satisfying, Master's and Ph. D. dissertations. The specific methodological foundation of much of this work had been exemplified in the study by Rudolf Klöpper et. al. (Rheinland-Pfalz in seiner Gliederung nach zentralörtlichen Bereichen, 1957). This study seems to have exempted most of the subsequent surveys of any further methodological work.

3. The term "Zentraler Ort" (central place) was used in the context of the regional economic policy program which was initiated in 1959 as part of the "Regional Promotion Policy." Initially sixteen "central places"were identified. The term was later changed to "Bendesausbau-Orte" (Federal Expansion Places).

4. Finally, there are "the central places" which the states have to select on the basis of more or less coordinated criteria as part of the Raumordnungspolitik. It seems that for the adoption of the a priori, empirically "perceived" four-level central place hierarchy, the influence of Gerhard Isbary and his research report had been decisive. Isbary argues in favor of this scheme: (1965, p. 32)

The investigation into the quantification of the (four) levels is based on the 'experienced fact' (Erfahrungstatsache) that for centuries it has been possible to classify settlements in almost all of Europe according to their population size, their service and central functions, thei $\bullet$ growth impulses, and their customs and social b shavior into four large classes: 
Urban capitals (grobstadtische Kapitalen), medium-size towns (Mittelstadte), small towns (Kleinstadte), and other settlements

They are a reality expressed in typical behavioral patterns of the population.

Thus, these distinctions contrast central places, their hierarchies, and spheres of influence (Hinterlands) as (l) deductive, "ideal" but still partial, intellectual constructs with (2) those of an inductive, inventory and classification-oriented nature; both represent primarily scientific exercises without direct planning orientation. By contrast, (3) and (4) represent adopted planning concepts, with (3) being by all accepted standards a misuse of the term "central place" since its accompanying measures were strictly "special function" oriented. (4), finally, is a planning concept designed to improve the supply of infrastructure services in an hierarchically-organized spatial system of settlements. Its underlying conceptual basis adopted has a heavily empiric rather than deductive nature.

\section{THEORETICAL ISS UES RELATED TO CENTRAL PLACES}

The dominant idea underlying Germanspatial planning is that of the existence of a fairly rigid hierarchy in the provision of goods and services, an idea which dates back to the contribution of Christaller and which, thus, bas ically ignores the modifications based on the work by August Lösch and others. The following theoretical issues come to mind in this context.

1. Central place theory is, in spite of its spatial generality, still a partial approach neglecting externalities and their distorting impact on a rigid Christaller pattern.

In addition, there is the inherently static character of the central place scheme as implemented or planned in Germany. The hierarchical ordering and the division of functions are based on past experiences, present technologies, and institutionaldivisions. By institutionalizing this scheme--however loose it may be--constraints are set which may hamper future, possibly very desirable, developments.

2. Any allocation of functions to hierarchical levels depends on the assumption made in regard to population distributions and comsumption functions, or, in a planning context, on the actual or planned population densities andactual or projected income levels and demand schedules. An a priori distribution of functions assumes that one can identify beforehand--on the Federal level--optimal sizes of functions, and that the size of functions are independent of the size of and various other characteristics of the city at which they are performed. In reality, such a situation may occur if the size of a function is in some manner institutionally determined and thus inflexible to local adjustments. The educational system will, in most cases, have to be assumed to be given. On the other hand, it seems that, for example, health facilities are much less subject to institutional rigidity. Thus, rigid prescription of quality and degree of specialization for these facilities for any one center could impose undesirable inefficiencies upon the system. 
3. Another related theoretical problem of the Germanimplementation of the Christaller central place concept is that "the re has to be a hierarchy of centers in which bigger centers always provide not just a greater variety of services but, in particular, supply at the same time all the goods and services that all smaller centers offer" (Böventer, 1969a, p. 189). This notion is basically sound for relatively low order, basic supply-type, services and infrastructure facilities in small centers. For larger or higher order cities, and thus also for higher functions, there is the complication that thesefunctions, without necessarily adding to or depending on external economies, do however contribute to the size, agglomeration, and congestion of these larger centers. Although dependent on large markets, they may actually suffer from being located in big cities.

It would be difficult to make any more specific a priori statements about the characteristics of desirable cross-hierarchical specialization except that the extent to which agglomeration in any one center can be avoided by planning measures will depend on the availability of alternative centers with structural complementaries at feasible distances (see Böventer, 1969a, p. 190 for further elaboration) and the available knowledge about optimal bundling of activities in terms of maximizing external economies within such bundles and minimizing diseconomies resulting from size and other factors. The relatively high density of rural settlements and the necessity to plan simultaneously for the provision of service functions as well as for employment centers also poses the question whether a more diversified spatial structure which presents more alternatives would be more feasible.

4. Since the central place network planning cannot begin with an ideal homogeneous plain but has to be superimposed upon an irregular system of existing centers, the re is the problem of having to choose between possibly equally qualified towns or cities. For the highorder centers (Oberzentrum), this problem hardly exists since they tend to stand out, are few in number, and can easily be spatially identified. However, as one descends to the level of Mittelzentrum, Unterzentrum, or even Kleinzentrum, the central place and growth potential differential decreases; thus, indeterminacy and the range for political bargaining increases (Hansmeyer, 1968, p. 45$)^{6}$. Here, a negative decision againstidentifying a given community for a given level may well have the negative impact of suppressing autonomous developments and local initiatives. One must agree that the development center concept of German regional economic policy has--at least in the past--provided for more flexibility, (Hansmeyer, op. cit.)

5. In spite of the fact that employment-oriented development center policies.have a longer history, it seems now that future industrialization schemes will accept the central place system and will determine those underindustrialized centers within the system which fulfill subsidization- and size requirements. Somediscussion had taken place in Germany before the minimum size requirements were codified. The basic problem consisted of finding a compromise between Germany small-town reality, the practical inability to create larger centers in relatively short planning periods, and the recommendations of the theoretical literature as well as the European Economic Community (EEC) for relatively large industrial centers. 
In this context, the Federal Government explicitly recognized a conflict between goals behind economic growth policies and the goal of social justice (equal provision of public services for all citizens) (BROB 1970, p. 37). The outcome of this discussion was that a "minimum of 20,000 people in the center and its hinterland" would be acceptable for the size of a "Schwerpunkt" within the regional action programs. The hinterland of such a center includes all communities from which the places of employment in the center can be reached within " $\frac{1}{2}$ to 1 hour." Distances of 1 hour should be the exceptions (BWM 1969a, p. 20). The 20,000 figure had been based on a report by Jochimson and Treuner (1967). Earlier writers had argued for a minimum of 30,000 in order to be able to fulfill the EEC recommendations of having at least 10 independent firms in the smallest industrial centers.

Here, the central place and development center policies appear to converge. Although the central place program is at present in its whole conception predominantly a consumer-oriented planning scheme, the industrial sector is not entirely neglected. In the 1968 Raumordnungs be richt (BROB, 1968, p. 155) the minimum requirements for the industrialization of central places have been similarly defined: The general minimum size for the labor shed of an industrial center shall be a population of 20,000 (this area being defined by a radius of approximately $15 \mathrm{~km}$ or a communting time of $\frac{1}{2}$ hour). Both the population minimumas well as the maximum time distance can be projected values (for the time after expected population growth and transport investments have taken effect). Moreover, the government anticipates that there will be a general tendency towards larger sizes of communities selected as industrial central places. (BROB 1970, p. 37). It also can be expected that the selection of "industrial central places" within the central place program and that of the "Schwerpunkte" (development centers) within the Regional Action Programs will eventually be merged.

\section{"TRICKLING" EFFECTS--CITY SIZES AND SPACING OF GROW TH CENTERS}

The proliferation of development centers of various kinds and sizes and the apparent dispersion of regional development funds provokes a more theoretical discussion of various interdependence effects which tie together questions of size and structure of centers, their spacing, the characteristics of their hinterland-linkages, as well as their so-to-speakforeland-linkages.

One of the implications of Hirschman's polarization and trickling-down arguments for regional planning is that following initial spatial concentration of public funds, in later stages, public funds, possibly generated by tax revenues from the initially supported projects, may have to be dispersed to complement "natural" trickling-down effects (Hirschman, 1958, pp. 187ff.). Subsequent interpretations have placed these trickling-down processes into hierarchical urban systems (Friedmann, 1966, pp. 28ff). Berry argued that in traditional societies, in the absence of well-developed urban hie rarchies, the spread-effect mechanism will tend to fail (Berry, 1969, p. 289). Natural trickling-down effects originating in larger growth centers will be directive and tend to discriminate against depressedareas with weakly developed infrastructures and peripherallocations. In the absense of possibilities to redirect these spread effects, centers will have to be established whose tricking-down effects are likely to focus upon or "be caught" within depressed areas. Thus, the delimitation of promotion regions and the size of identified growth centers to be supported should change during the process of ec- 
onomic development. Following John Lewis' suggestion of "decentralizingdownward, " a gradual shift to smaller growth centers will eventually encompass the total area to be developed (quoted in Berry, 1969, p. 290).

During the early stages of Germany's recovery, growth was supported wherever it occurred, namely, predominantly in larger cities of industrial areas. Thus, after full employment was reached, public funds shifted to lagging regions and again supported growth in smaller cities and rural areas whenever it occurred. Indeed, there were indications that at least initially development centers (Ausbauorte) were determined and subsidized after an interest was expressed by a firm to locate there (Kroner, 1964, pp. $\overline{449 \mathrm{ff}}$.). Logically, regional supportwould be focused on smaller and smaller centers as one encircles the regional problem. Making use of agglomeration economies in larger cities, trickling-down effects will be effective only in immediate hinterlands as well as possible in hierarchically subordinated smaller cities which, one could argue in a way would be prepared for subsequent direct government subsidization. Although one does not expect that aggregate regions loose their status of relative "depression, "one would expect that the pockets of depression become more and more scatteredas the center-oriented growth policy closes in on those regions which have been most disadvantaged or peripheral relative to earlier developed centers. Although some scattering seems to haveoccurred in Germany, the expected decline in centers to be supported has not.

In fact, German regional and spatial planning policies do not seem to have followed this "decentralization-downward" strategy (Berry, 1969, p. 290). Early growth centers had been relatively small in size. Later, hierarchical elements were introduced with slightly increasing average sizes of growth centers to be supported. Such a "centralization-upward" policy was in no uncertain terms advised by E. A. J. Johnson for India (1970, p.212):

The lack of town and small cities must by some means be corrected. Obviously, a whole hierarchy of central places cannot be preplanned orquickly built. What can be done, however, it to coagulate programmed investments, both private and public, into new, well located capital clusters that can become nuclei a round which the 'powerful forces of spontaneity' can gradually begin to exert their influence. . . contrived investment clusters can become the nuclei for almost any desired number of new agro-urban center places in underdeveloped countries. It is here that the process of town buildings must begin; on this score the Löschean sequence from small to larger central places should be the prescription, because the larger, intermediate central places will have no true function unless the smallest market towns have begun to take form.

Can this argument for a small-town start in a center-oriented policy be--mutatis mutandis--transferred to the German scene? High rural densities would speak in its favor. "Structural features of centers tend to be the same from region to region regardless of the stage or the level of regional development" (Hodge, 1968, p. 21). From a pragmatic point of view, it may be the lack of capital, available land, or appropriate planning tools as well as the existence of institutional and political barriers which would render a rapid, necessarily expensive creation of relatively large, intermedrate centers impractical. Marginal changes of the status quo, that is, a selective marginal expansion of many existing centers is much more acceptable, institutionally and politically, particularly as long as the theoretical problems remain largely unsolved. The Central Place program is, in gen- 
eral, a more balanced simultaneous hierarchical approach than the one suggested by Johnson. However, the fact that there is a relative lack of a priori higher-level centers in weak regions (i.e., relatively more higher-order centers have to be expanded to their assigned role than lower order centers) automatically discriminates in favor of Johnson's argument. In general, the same is truefor the growth center policies of the Federal government. Initially, relatively few and small centers were supported. Subsequently, the number mushroomed and the whole program received a somewhat hierarchical character with selected, usually larger, strategic centers receiving certain preferences. Moreover, while the government was concerned with reducing regional inequalities, structural problems surfaced in larger industrial cities and agglomerations (Ruhr, Saar, Hamburg, Kiel) during the recession in 1966 and 1967 forcing the government to support orderly structural change in industrially established regions before the problem of lagging regions could be brought to a satisfactory solution.

Small development centers seem to have one definite advantage: trickling-down effects are limited and--as income multiplier effects--fairly well identifyable. Injections of public funds will leak heavily to larger centers, i. e., to the "trickling-up foreland" (rather than to the "trickling-down hinterland"). Vida Nichols' conclusion drawn from research in Georgia expresses similar small center preference: (1969, p. 199).

. . although it is probably advisable to concentrate investment in that town in a region which has the strongest linkages, there are also advantages to be gained from injecting capital into lower order centres, or even the agricultural base, because increases in incomes in these places will generate strong income multipliers in higher order centres but not the other way around.

In such situations, directional manipulations of "trickling-up effects" would be crucial in order to ensure their absorption by the appropriate intermediate centers, if they exist! Usually--and Germany is no exception--the structurally weakest regions also suffer from an insufficiently developed intermediate city-size level and a re dominated by a large metropolis: Hamburg dominating large parts of rural,lagging Schleswig-Holstein and Munich backwashing Eastern Bavaria.

\section{CENTRAL PLACES AS "RURAL RETENTION CENTERS"}

One of the more pragmatic notions of a growth center policy is that a planned center can potentially fulfill the double role of demagnetizing existing overcongested agglomerations as well as attracting migrants from rural, supposedly overpopulated areas. It is generally agreed that the success of such a dual objective lies in the kind and size of the center which is placed between the rural or small town migrant and the metropolitan areas. The larger the center, the more effectively will it serveas an industrial countermagnet to congested areas; however, the more it will also be subjected to congestion itself. Presumably, smaller centers would imply a larger number of centers possibly closer to the source of migration: the social and economic friction of distance for potential migrants would decline, but the center may assume the character of atransit location for migrants on the way to "where the action is."

Considering various functional alternatives for planned growth centers, one cannot but conclude that the German central place and growth centers should be termed "rural-labor-force retention centers." In postwar Germany many, "rural renewal" has always been strongly biased in favor of what is 
called "active renewal". "Passive" renewal, the propagation of outmigration, had the stigma of a social uprooting with the inherent danger of contributing to the urban-industrial proletariat. The possibility of maintaining a part-time farming structure by dispersing industries into rural areas made the policy of structural adjustments in the agricultural sector acceptable to the Christian Democratic government, that is, industrialization without losing the conservative rural vote.

Such a retention policy is in direct opposition to the European Economic Commission's agricultural policy which--according to the Mansholt plan-aims at a rigorous consolidation and rationalization of farms. While the Federal government tolerates the part-time farming pattern existing in many parts of Germany, the state of Bavaria--generally considered to be one of the more conservative of the ten states--has just passed a new "Act for the promotion of Bavarian agriculture" effective January 1, 1971. Objectives of this new law are, according to Article I:

1. to secure the position of Bavarian agriculture--with its full-and part-time farms--within society

2. to contribute to maintaining rural space as "Kulturlandschaft."

The preface explains that animprovement of living conditions also can come about by combining agricultural and non-agricultural employment. Everybody should have the "opportunity to retain his property and fa rm. "' Geiersberger, 1971).

Outmigration as an explicit regional planning instrument has practically not been used since the end of the refugee resettlement program. In fact, one of the explicit purposes of the development center (Schwerpunkte) policy is "to prevent a passive Sanierung (renewal)." (BWM 1969a, p. 21).

\section{CONCLUSION}

An overall interpretation of the German regional policies would stress the dominance of social and political factors and the significance of the a priori acceptance of present population distributions. The general neglect of economic factors and repercussions would invite the concluding hypothesis that structural imbalances a re likely to be perpetuated: Rural and small-town industries in relative isolation will be viable only through rigid corporate linkages to and domination by parent plants in the industrial districts. Avoiding this branch plant atmosphere seems to be possible only by prolonged public assistance. The improvement of "living and working conditions" is likely to cover up only temporarily the lack of job diversity for vertical mobility. The pattern of relatively low labor productivity is likely to be perpetuated by a continuing influx of labor-intensive, low-productivity industries which are being pushed out of higher-productivity regions; they will not only continue to absorb the naturally underemployed members of farm families, but by their very existence reinforce the belief of the small farmer that he has to maintain his farm and have two jobs to make a living. It is questionable whether the present programs, even with the improvement of the past three years, will be "massive" enough to justify their extensive dispersion through a network of relatively small development centers. An evaluation of their success will be the more difficult the more the generally favorable economic climate in the country is able to hide regional structural imbalances. 
TABLE 1. DISTRIBUTION OF NEWLY ESTABLISHED AND RELOCATED PLANTS BY SIZE OF COMMUNITY

1964 and 1965

\begin{tabular}{lcccrc}
$\begin{array}{l}\text { Community } \\
\text { Size Class }\end{array}$ & $\begin{array}{c}\text { Number of } \\
\text { Plants }\end{array}$ & $\begin{array}{c}\% \\
\text { Employ- } \\
\text { ment }\end{array}$ & $\begin{array}{c}\text { Ave rage } \\
\text { Plant Size }\end{array}$ \\
\hline less than 1,000 & 257 & 15.1 & 7,812 & 9.9 & 30.4 \\
$1,000-3,000$ & 502 & 29.5 & 19,641 & 25.0 & 39.1 \\
$3,000-5,000$ & 214 & 12.6 & 10,303 & 13.1 & 48.1 \\
$5,000-10,000$ & 256 & 15.1 & 12,850 & 16.3 & 50.2 \\
$10,000-20,000$ & 166 & 9.6 & 8,648 & 11.0 & 52.1 \\
$20,000-50,000$ & 119 & 7.0 & 7,803 & 9.9 & 65.6 \\
50,000 and more & 186 & 10.9 & 11,606 & 14.8 & 62.4 \\
TOTAL & 1,7000 & 100 & 78,663 & 100 & 46.3 \\
\hline
\end{tabular}

Source: Der Bundesminister fur Arbeit und Sozialordnung. Die Standortwahl der Industriebetrieb in den Jahren 1964 und 1965, Bonn 1966, p. 21. 


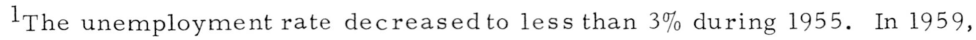
substantial "overemployment" was already in evidence in many regions.

2 The sharecf the agricultural labor force in the total gainfully employed West German labor force decreased from 25\% in 1950 to $13 \%$ in 1961 and $10.3 \%$ in 1968 .

${ }^{3}$ Not surprisingly, the attractiveness of rural areas for the location of new plants sharply declined during the 1966-1967 recession.

${ }^{4}$ A systematic critical discussion of the evolution of various goals, te rms, and concepts during the drafting of the Raumordnungsgesetz can be found in Horst Zimmermann, "Zielvorstellungen in der Raumordnungspolitik des Bundes," Jahrb. f. Sozialwissenschaften, 17 (2), 1966, 225045.

${ }^{5}$ This Institute für Landeskunde is part of the Bundesforschungsanstalt für Landeskunde and Raumforschung in Bad Godesberg and is located in the same building as the Institute für Raumforschung. Both institutes are engaged in central place research, the former supposedly strictly from "the" geographic point of view, the latter from the spatialplanning (Raumordnung) aspect. It is truly amazing to what extent the bureaucratic divisions between these two institutions and the underlying longstanding, largely unjustified, differences between "Geography" (Landeskunde)and "Raumordnung influence the lack of interaction and the type of work done under the same roof, particularly in view of the fact that the Institute für Landeskunde has been involved in central place planning research sponsored by at least one state planning agency (Kluczka, 1970).

${ }^{6}$ Community and county politicians can be expected to leave nothing undone to receive their share of the "subsidization cake." Appropriately, the central place scheme has already been termed the "Landratsbefriedigungspolitik" (County-supervisor-appeasement policy).

${ }^{7}$ Specific recommendations regarding the industrial functions of central places include: (BROB 1968, p. 155).

(1) Industrial locations to be developed in the future shall be central places at the same time or shall be in close contact with them.

(2) Whenever central places are in close spatial proximity to each other, industrial locations shall--whenever possible--serve the labor force of the hinterlands of both central places.

(3) For choosing among alternative communities as potential industrial locations, the following considerations shall be taken into account:

(a) the initial condition, particularly the number and structure of already existing jobs and the existence of infrastructure facilities

(b) the suitability of the community for providing central place services to a hinterland

(c) a non-discriminatory accessibility for all places in the hinterland.

(4) The promotion of new industries shall aim also at a differentiation of the regional production program. 


\section{REFERENCES}

Albert, Wolfgage, Zeilgewinnung und Entscheidungsfindung für Inf rastruktuprogramms," in: Jochimsen, R. and E.E. Simonis, eds., Theorie und Praxis der Infrastrukturpolitik, Berline: Duncker \& Humblot, 1970, pp. 237-254.

Berry, Brian J. L., "Relationships between Regional Economic Development and the Urban System: The Case of Chile," Tijdschrift voor Economische on Sociale Geografie, Vol. 60 (5), 1969, pp. 283-307.

von Borries, Hans Wilkin, Ökonomische Grundlogen derwestdeutschen Siedlungsstrucktur. Hanover: Gebr. Janecke Verlag, 1969.

von Boventer, Edwin, "Diskussion," in: E. Schneider, ed., Rationale Wirtschaftspolitik und Planung in der Wirtschaft von heute, Berlin: Duncker \& Humblot, 1967, pp. 283-285. "Regional E onomic Problems in West Germany," in: E.A. G. Robinson, ed., BackwardAreas in Advanced Countries, London: Macmillan, 1969, pp. 171-195.

ten Brink, M. and G. Kroner. "Zwei neue Karten zur regionalen Wirtscha tspolitik, !. Informationen (Institut für Rauınordnung) Vo. 20 (2), January 1970 , pp. 57-60.

Bundes-Raumordnungsgesetz (BRQG) of April 8, 1965, Bundesgestetzblatt I, p. 306 .

Bundes regierung, Raumordnungsbericht 1968 (BROB 1968), Deutscher Bundestag, 5. Wahlperiode, Drucksache V/3958, Bonn 1969.

Bundes regierung, Raumordnungs bericht 1970 (BROB 1970), Deuts che r Bundestag, 6. Wahlperiode, Drucksache V/1340, Bonn 1970.

Der Bundesminister für Arbeit und Sozialordnung. Die Standortwahl der Industriebetriebe in den Jahren 1964 und 1965, Bonn 1966.

Bundesministerium fur Wirtschaft. Strukturbericht 1969 (BWM 1969b), BWMI Texte No. 75, Bonn, July 1969 (Mimeo). Intensivierung und Koordinierung der Regionalen Strukturpolitik (BWM 1969a), Bonn 1969.

Commission of the European Communities. A Regional Policy for the Community. Luxemburg, 1969.

Friedmann, John, Regional Development Policy: A Case Study of Venezuela. Cambridge: M.I. T. Press 1966.

Geiersberger, Erich. "Zwölf Jahre zu spät: Bayern als Vorreiter für eine neue Agrarpolitik," Die Zeit, No. 14, April 6, 1971, p. 17.

Hansmeyer, Karl-Heinrich, "Ziele und Träger regionaler Wirtschaftspolitik, " in: H.K. Schneider, ed., Beiträge zur Regionalpolitik. Berlin: Duncker \& Hamblot 1968, pp. 36-60.

Hirschman, Albert O. The Strategy of Economic Development, New Haven: Yale University Press 1958.

Hodge, Gerald, "Urban Structure and Regional Development, " Papers of the Regional Science Association 21 (1968), pp. 101-123. 
Isbary, Gerhard, Zentrale Orto und Versorgungsbereiche: Zur Quantifizierung der Zentralen Orte in der Bundesrepublik Deutschland, Bad Godesberg: Institute fur Raumforschung, 1965.

Isbary, G., H.J. von der Heide and G. Müller. Gebiete mitgesunder Strukturen und Lebensbedingunger: Merkmale und Abgrenzung. Hannover: Jänecke Verlag, 1969.

Jochimsen, R. and P. Treuner, Zentrale Orte in ländlichen Räumen. Mitteilungen aus dem Institute für Raumforschung, Bad Godesberg, 1967, Heft 58.

Johnson E. A. J. The Organization of Space in Developing Countries. Cambridge, Mass.: Harvard University Press, 1970.

Klöpper R., J. Körber and E. Meynen, Rheinland-Pfalz in seniør Gliederung nach zentralörtlichen Bereichen. Remagen: Bundesanstanlt für Landeskunde, 1957.

Kluczka, Georg. Nordrhein-Westfalen in seiner Gliederung nach zentralörtlichen Bereichen: Eine geographisch-landeskundliche Bestandsaufnahme 1964-1968. Düsseldorf: Staatskanziei 1970.

Kroner, Günter, "Die zentralenOrte in Wissenschaft und Raumordnungspolitik," Informationen (Institute für Raumforschung), Vol. 14 (13), 1964, pp. $421-456$.

Kroner, Günter, "Die Bestimmung zentralerOrte durch die Bundesländer,' Informationen (Institute für Raumordnung), Vol. 20 (4), 1970, pp. 97-109.

Mayhew, Alan, "Regional Planning and the Development Areas in West Germany," Regional Studies, Vol. 3, 1969, pp. 73-79.

Nichols, Vida, "Growth Poles: An Evaluation of their Propulsive Effect," Environment and Planning, Vol. 1 (2), 1969, pp. 193-208.

OECD: The Regional Factor in Economic Development: Policies in 15 Industrialized OECD Countries, Paris 1970.

Raum und Ordnung: Tatsachen und Meinungen zur Raumordnung und Kommunalpolitik published by: Bundesministerium des Innern, Bonn.

Schmidt, Karl-Heinz. Regional politik und BetriebsgröBenstruktur. Göttingen: O. Schwarz Verlag, 1970.

Storbeck, Dietrich, "Area Development in the Federal Republic of Germany,' in: Area Development Policies in Britain and the Common Market, Washington D. C.: U.S. Department of Commerce, 1965, pp. 171-213.

Weigt, Ernst, "Stảndorte neuer Industriebetriebe in Franken und derOberpfalz unter dem Gesichtspunkt von Nachbarschaft und Fühlungesvorteil, in: Theodor Kraus-Festschrift, Bad Godesberg: Bundesanstalt für Landeskunde and Raumforschung, 1959 .

Wiek, Klaus D. Regionale Schwerpunkte und Schwächezonen in der Bevölke rung s-Erwerbs- und Inf rastruktur Deutschlands. Bad Godesberg: Bundesforschungsanstalt für Landeskunde und Raumordnung, 1967.

Zimmermann, Horst, "Zielvorstellungen in der Raumordnungspolitik des Bundes, " Jahrb. für Sozialwissenschaften, Vol. 17 (2), 1966, pp. 225-245. 